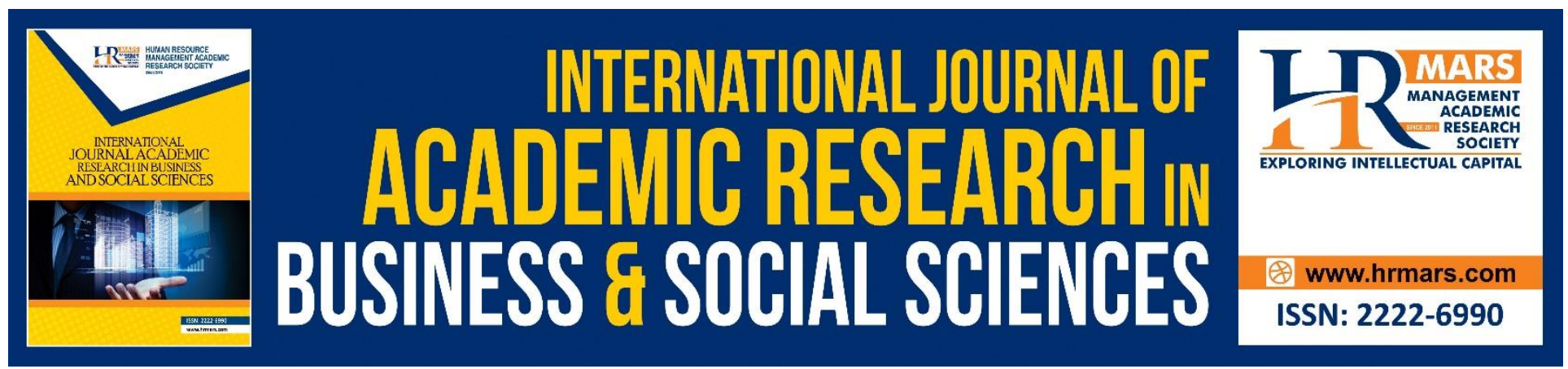

\title{
Studies on Takaful Agent Behaviour against Consumers
}

\author{
Nor Arini Abdullah
}

To Link this Article: http://dx.doi.org/10.6007/IJARBSS/v8-i11/4975

DOI: $10.6007 /$ IJARBSS/v8-i11/4975

Received: 29 Sept 2018, Revised: 17 Oct 2018, Accepted: 03 Nov 2018

Published Online: 11 Nov 2018

In-Text Citation: (Abdullah, 2018)

To Cite this Article: Abdullah, N. A. (2018). Studies on Takaful Agent Behaviour against Consumers. International Journal of Academic Research in Business and Social Sciences, 8(11), 973-982.

Copyright: (C) 2018 The Author(s)

Published by Human Resource Management Academic Research Society (www.hrmars.com)

This article is published under the Creative Commons Attribution (CC BY 4.0) license. Anyone may reproduce, distribute, translate and create derivative works of this article (for both commercial and non-commercial purposes), subject to full attribution to the original publication and authors. The full terms of this license may be seen at: http://creativecommons.org/licences/by/4.0/legalcode

Vol. 8, No. 11, 2018, Pg. 973 - 982

http://hrmars.com/index.php/pages/detail/IJARBSS

JOURNAL HOMEPAGE

Full Terms \& Conditions of access and use can be found at http://hrmars.com/index.php/pages/detail/publication-ethics 


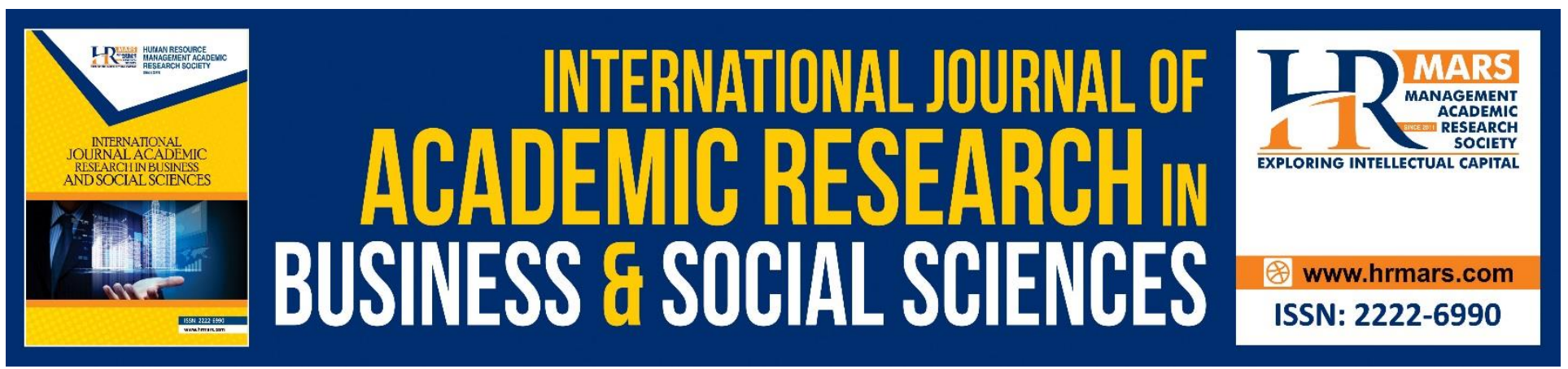

\title{
Studies on Takaful Agent Behaviour against Consumers
}

\author{
Nor Arini Abdullah \\ Centre For Islamic Development Management Studies (ISDEV), University of Science Malaysia, \\ Penang \\ Email: arini_polaris@yahoo.com
}

\begin{abstract}
Takaful is one of the Islamic financial instruments that emphasize the principles of brotherhood, unity and mutual cooperation in providing assistance to the participants who is in need of aid. Regular takaful participants deal with takaful agents to promote their products and takaful protection plans to the public. Takaful agents act as representatives for the consumers in managing their takaful plan participation procedures while at the same time providing a transparent and clear information to the consumers regarding takaful plans. However, there are some negative issues that arise regarding takaful agents in representing the consumers such as unethical management and unable to provide an accurate information of the takaful. Thus, the question arise, is the behaviour of a negative takaful agent arising from the behaviour of the takaful consumers or is it actually caused by the behaviour of takaful agent itself? Hence, this study aims to examine the negative behaviour of takaful agents with consumers in Malaysia. There are two objectives of the study. First, to identify the behaviour of takaful agent against consumers in previous studies; and second, to analyse the negative behaviours of takaful agents with consumers in previous studies. The findings reveal that among the few of the negative behaviour of takaful agents is deliberately concealing information on products and services, and being unable to identify the needs of the takaful participants resulting in the failure to provide suitable products to the participants.
\end{abstract}

Keywords: Agents Behaviour, Consumers, Takaful

\section{Introduction}

Takaful is an Islamic investment scheme that emphasize the principle of brotherhood, unity and cooperation in providing assistance to the participants that is in need of some aid. Takaful agents is the first party to meet the community as to provide information on the product or plan that is appropriate with the participants' request (Khuzana Ab Rahaman \& Farah Adibah Mohd Apandi, 2016). Takaful agents also act as a mediator to the participants in managing their takaful plan entry procedure. These agents carry the image of a takaful company while at the same time playing a role 
INTERNATIONAL JOURNAL OF ACADEMIC RESEARCH IN BUSINESS AND SOCIAL SCIENCES Vol. 8, No. 11, Nov, 2018, E-ISSN: 2222-6990 @ 2018 HRMARS

in providing a transparent and clear information to the participants so that the quality of good relations between the parties can be perfectly maintained.

Takaful agents plays an important role with the takaful consumers especially in identifying takaful products and providing the best services to the consumers. However, there are some behaviour of takaful agents in takaful management that are unethical. The unpleasant behaviour of a takaful agent will undermine the trust and satisfaction of the consumers of the selected takaful. Thus, the question arises, is the behaviour of a negative takaful agent arising from the behaviour of takaful consumers or actually caused by the behaviour of the takaful agent themselves? To answer this question, the paper contain two objectives. First, to identify the behaviour of takaful agents with consumers in previous studies; and second, to analyse the negative behaviours of takaful agents with consumers in previous studies.

In order to achieve the two objectives, this descriptive study will only be involving secondary data. The secondary data is obtained through document review. Then, the data gained in this study will be analysed by the qualitative content analysis method. Generally, the results of this data analysis will be divided into four parts. First, this paper will discuss the definition of the takaful system; second, identifying the behaviour of takaful agents with consumers; third, analysing the behaviour of takaful agents with users and to be finalized with a conclusion.

\section{Takaful System}

Kafala is the root word for takaful. It means to guarantee, protect or care. Takaful is a noun derived from the verb takafala which means mutual guarantee, mutual protection and mutual caring (Mahmud \& Kader, 2012). These concepts are the foundation of takaful system (Borhan \& Saari, 2003). According to the definition issued by Takaful Ikhlas Company on their website, the takaful system is based on the concept of cooperation, responsibility, guarantees, protection and mutual assistance among participants. At the same time, takaful operations are the provision of shared contributions among other participants by giving and providing assistance to participants who are suffering from calamities. According to Isa \& Deni (2009), the term takaful can be interpreted as takaful scheme based on the relationship of Muslim brotherhood, mutual responsibility towards each other as well as the mutual cooperation between takaful participants. The definition given by Isa \& Deni (2009) is similar to the definition given by Abd Sattar Abu Ghuddah (2008) that defines takaful as participation of an individual in an Islamic investment scheme that emphasize the concept of brotherhood, cooperation and mutual guarantee between takaful participants as they will help each other in the event misfortune on other participants of the takaful. Mohd Noor \& Zakaria (2010) define takaful as a concept of cooperation that is allowed by the Islamic law and it is based on the tabarru' (donation) and ta'awun (helping).

The definition given by Abd Sattar Abu Ghuddah (2008), Mohd Noor \& Zakaria (2010) supported the definition given by Billah (2006) stating that in the takaful system, there are several important aspects contained in the definitions that lead to the need for takaful contracts to be practiced by Muslims. There are five important aspects that have been expressed by the author, the 
first aspect is the agreement between participating members for the common good and the second being the element of tabarru' in takaful operations. The tabarru' element is intended to divide losses and distributing liabilities through the community savings system. The third aspect in the definition is if there are participants who is in need, each contributor have to agree to provide aid by using the takaful savings money. The fourth aspect is there should no elements of uncertainty regarding subscription and compensation in the takaful system. The last aspect is that the takaful scheme is not an Islamic financial instrument that takes advantage of the costs incurred by others.

At the same time, the takaful system acts as a contractual agreement between the takaful companies and participants. In the contract, takaful participants will agree to contribute money into the takaful fund. The funds donated by participants will be managed by the companies (Ab Mumin Ab Ghani, 1997). Takaful participants will be compensated by the takaful fund if they face any accidents or loss. The participants must agree to contribute part of their contributions to other takaful participants in the event of any accidents or loss that befall to other participants. Therefore, it can be concluded that takaful is an Islamic financial instrument that emphasize the concept of mutual assistance, mutual cooperation, mutual responsibilities among each other and independent of any elements of uncertainty, usury and gambling.

\section{Takaful Agents Behaviour Against Consumers}

The behaviour of takaful agents in the takaful industry has been studied by past researchers which among them are consist of Hamid, Ab Rahman, \& Nor (2012), Cheng, Hsieh \& Yang (2014), Aziz, Ghani, \& Shaari (2015), Chen and Mau (2009), Ahmad, \& Sungip (2008), Eastman and Drennan (1997), Marcum and Robin (2003), Cooper and Frank (2002), Howe, Hoffman and Hardigree (1994) and Cooper and Frank (1991).

Based on past studies, researchers have found various behaviour of the agents particularly the behaviour of agents towards the consumers. Hamid, Ab Rahman, \& Nor (2012) have studied the leadership among takaful agents on the performance of the takaful industry in Malaysia while Aziz, Ghani, \& Shaari (2015) discussed on the factors that contributes to the ethical behaviour among takaful agents.

Other than that, the study of Cheng, Hsieh and Yang (2014), Mei and Mau (2009)and Ahmad, \& Sungip (2008) are related with the takaful service. Cheng, Hsieh and Yang (2014), Mei and Mau (2009) studies explored on ethical issues related to the offering of services offered by the agents while the study of Ahmad, \& Sungip (2008) evaluates expectations and perception of takaful consumers towards the services offered by takaful companies. May and Mau (2009) study found that if the consumers' trust in agents decreases, the likelihood of them leaving the takaful company is higher. However, Cheng, Hsieh \& Yang (2014) found that the differences in age and experience among the respondents displays a significant impact on unethical behaviour among agents. 
INTERNATIONAL JOURNAL OF ACADEMIC RESEARCH IN BUSINESS AND SOCIAL SCIENCES Vol. 8, No. 11, Nov, 2018, E-ISSN: 2222-6990 (C) 2018 HRMARS

Cooper and Frank (1991) studied the respondents' perceptions of the major ethical issues faced in the takaful industry. In 2002, Cooper \& Frank (2002) again conducted studies on ethical issues but this time the issues in focus are regarding the challenges and ethical issues in the takaful industry.

Eastman and Drennan (1997), Marcum and Robin (2003) and Howe, Hoffman and Hardigree (1994) studied the ethics and behavioural attitudes of the agents towards their customers, however the study conducted by Eastman and Drennnan (1997) is a study of the implications of education among takaful agents with students.

From the total results of the studies, the researcher have listed the behaviour of the agents found by previous researchers in the form of a table. Table 1 below shows a summary of the behaviour of the agent with the consumers.

Table 1. List of Researcher Names and Takaful Agents Behaviour Study Results

\begin{tabular}{|c|c|c|c|c|c|}
\hline No. & Researcher & \multicolumn{2}{|c|}{ Type/Methodology } & \multicolumn{2}{|c|}{ Results of Study on Agents Behaviour } \\
\hline 1 & $\begin{array}{l}\text { Hamid, Ab Rahman, \& } \\
\text { Nor (2012) }\end{array}$ & & $\begin{array}{l}\text { Quantitative } \\
\text { Research } \\
\text { A total of } 170 \\
\text { respondents are } \\
\text { among takaful agents } \\
\text { on Malaysia. } \\
\text { Data analysed using } \\
\text { SPSS software version } \\
17.0\end{array}$ & $\begin{array}{l}\text { i } \\
\text { ii } \\
\text { iii }\end{array}$ & $\begin{array}{l}\text { Lacking skills to attract participants } \\
\text { and retain consumers } \\
\text { Do not know how to communicate } \\
\text { Do not know how to disclose about } \\
\text { takaful products and fail to } \\
\text { persuade consumers }\end{array}$ \\
\hline 2 & $\begin{array}{l}\text { Chia Yi Cheng, Chia } \\
\text { Hung hsieh \& Yu Song } \\
\text { Yang (2014) }\end{array}$ & & $\begin{array}{l}\text { Quantitative Research } \\
\text { A total of } 957 \\
\text { respondents } \\
\text { Data analysed using } \\
\text { SPSS software. }\end{array}$ & ii & $\begin{array}{l}\text { Wrong and false information } \\
\text { regarding the products and } \\
\text { services } \\
\text { Deliberately hides information } \\
\text { regarding the products and } \\
\text { services } \\
\text { Unable to identify the appropriate } \\
\text { product for the consumers } \\
\text { Lack understanding regarding the } \\
\text { concept and knowledge of takaful } \\
\text { Behaviour that affects the } \\
\text { reputation of the company } \\
\text { Do not fulfil responsibilities on } \\
\text { tasks due to conflict of interest }\end{array}$ \\
\hline 3 & $\begin{array}{l}\text { Aziz, Ghani, \& Shaari } \\
\text { (2015) }\end{array}$ & $\begin{array}{l}\mathrm{i} \\
\mathrm{ii}\end{array}$ & $\begin{array}{l}\text { Qualitative Research } \\
\text { Unstructured } \\
\text { interviews on focused } \\
\text { group (Branch }\end{array}$ & $\begin{array}{l}\mathrm{i} \\
\mathrm{ii}\end{array}$ & $\begin{array}{l}\text { Provide false information } \\
\text { Lack skills to provide } \\
\text { understanding to consumers. }\end{array}$ \\
\hline
\end{tabular}


INTERNATIONAL JOURNAL OF ACADEMIC RESEARCH IN BUSINESS AND SOCIAL SCIENCES Vol. 8, No. 11, Nov, 2018, E-ISSN: 2222-6990 @ 2018 HRMARS

\begin{tabular}{|c|c|c|c|c|c|}
\hline & & & $\begin{array}{l}\text { Manager, Executive } \\
\text { Officers and Takaful } \\
\text { Agents) }\end{array}$ & iii & $\begin{array}{l}\text { Do not understand the needs of } \\
\text { consumers. }\end{array}$ \\
\hline 4 & $\begin{array}{l}\text { Mei Fang Chen \& Liang } \\
\text { Hung Mau (2009) }\end{array}$ & $\begin{array}{l}\text { i } \\
\text { ii }\end{array}$ & $\begin{array}{l}\text { Quantitative Research } \\
\text { A total of } 215 \\
\text { respondents chosen. }\end{array}$ & & $\begin{array}{l}\text { i Unable to understand } \\
\text { consumers' needs. } \\
\text { ii Do not understand the } \\
\text { concept of takaful and the } \\
\text { tasks that need to be done }\end{array}$ \\
\hline 5 & $\begin{array}{l}\text { Eastman, J.K., Eastman, } \\
\text { K.L., \& Drennan, R.B } \\
\text { (1997) }\end{array}$ & $\begin{array}{l}\text { i } \\
\text { ii }\end{array}$ & $\begin{array}{l}\text { Quantitative Research } \\
\text { Questionnaire is } \\
\text { distributed to the } \\
\text { agents }\end{array}$ & i & $\begin{array}{l}\text { "Down-selling" - Agents convincing } \\
\text { the consumers to choose a low } \\
\text { quality product. } \\
\text { "Over-selling" - Agents convincing } \\
\text { consumers to choose products } \\
\text { that the consumer does not need. }\end{array}$ \\
\hline 6 & Ahmad, \& Sungip (2008) & i & $\begin{array}{l}\text { Quantitative Research } \\
\text { Approximately } 319 \\
\text { respondents among } \\
\text { consumers to } \\
\text { evaluate consumers } \\
\text { perceptions and } \\
\text { expectations of } \\
\text { service quality }\end{array}$ & $\begin{array}{l}\text { i } \\
\text { ii } \\
\text { iii }\end{array}$ & $\begin{array}{l}\text { Intentionally delaying the } \\
\text { settlement claims } \\
\text { Providing incomplete or incorrect } \\
\text { information } \\
\text { Lack professionalism } \\
\text { Services that are less customer- } \\
\text { friendly. }\end{array}$ \\
\hline 7 & $\begin{array}{l}\text { Marcum and Robin } \\
\text { (2003) }\end{array}$ & i & $\begin{array}{l}\text { Quantitative Research } \\
\text { Questionnaire } \\
\text { distributions to the } \\
\text { agents }\end{array}$ & $\mathrm{i}$ & $\begin{array}{l}\text { Engage in other part-time work } \\
\text { without the knowledge of the } \\
\text { company and advisor until it } \\
\text { affects the task as an agent }\end{array}$ \\
\hline 8 & Cooper \& Frank (2002) & i & $\begin{array}{l}\text { Quantitative Research } \\
\text { Respondents consist } \\
\text { of } 1500 \text { MDRT } \\
\text { (Million Dollar Round } \\
\text { Table) members }\end{array}$ & $\begin{array}{l}\text { i } \\
\text { ii } \\
\text { iii }\end{array}$ & $\begin{array}{l}\text { Fail to provide immediate and } \\
\text { honest answer to customer } \\
\text { requests. } \\
\text { Conflicts of interest involving work } \\
\text { and relationships with finances or } \\
\text { with consumers. } \\
\text { Failed to achieve objective. }\end{array}$ \\
\hline 9 & $\begin{array}{l}\text { Howe, Hoffman \& } \\
\text { Hardigree (1994) }\end{array}$ & i & $\begin{array}{l}\text { Quantitative Research } \\
\text { Data collected by } \\
\text { distributing } \\
\text { questionnaires to } \\
1200 \text { respondents }\end{array}$ & $\begin{array}{l}\text { i } \\
\text { ii }\end{array}$ & $\begin{array}{l}\text { Providing false information } \\
\text { Assisting users to breach claims } \\
\text { against the company }\end{array}$ \\
\hline
\end{tabular}


INTERNATIONAL JOURNAL OF ACADEMIC RESEARCH IN BUSINESS AND SOCIAL SCIENCES Vol. 8, No. 11, Nov, 2018, E-ISSN: 2222-6990 @ 2018 HRMARS

\begin{tabular}{|c|c|c|c|c|c|}
\hline 10 & Cooper \& Frank (1991) & $\begin{array}{l}\text { i } \\
\text { ii }\end{array}$ & $\begin{array}{l}\text { Quantitative Research } \\
\text { Questionnaires } \\
\text { distributed to } 1173 \\
\text { members of CLU } \\
\text { (Chartered Life } \\
\text { Underwriter) and } \\
\text { ChFc (Chartered } \\
\text { Financial Consultant) }\end{array}$ & $\begin{array}{l}\text { i } \\
\text { ii } \\
\text { iii } \\
\text { iv }\end{array}$ & $\begin{array}{l}\text { Providing false and misleading } \\
\text { information to consumers. } \\
\text { Fail to identify consumers' needs. } \\
\text { Conflict of interest } \\
\text { Defaming other agents to } \\
\text { consumer } \\
\text { Inefficient in managing consumers' } \\
\text { problems. }\end{array}$ \\
\hline
\end{tabular}

\section{Analysis Of Studies On Takaful Agents Behaviour Against Consumers}

Based on previous studies, at least 13 of the agents behaviour have been identified. These behavior have been reduced to become 13 major agents behaviour. After analyse past studies, the researcher found that the behaviour of providing false information regarding takaful products and services is the most dominant agents' behaviour among others. This is evident by the number of frequencies of the behaviour being the highest with five times the frequency. Hence, it is arguable that almost half of previous researchers find that agents who do not provide true and clear information are the behaviour of unethical agents in carrying out their duties as a liaison between takaful companies and consumers.

Other than that, the behaviour of agents that did not know and understand the consumers' needs and agents' behaviour on other unethical issues shares the same frequency which is four times the frequency. The researcher have reduced some of the behaviour to other ethical issues. Other ethical issues are behaviour that affects the reputation of the company, services rendered being non customer-friendly, helping consumers to mislead the company, defaming other agents to the consumers, and inefficiency in handling consumers' problems. These behaviour have negatively impact the takaful company. This matter has been stated by Hamid, Ab Rahman, \& Nor (2012). They state that the problems in the behaviour of agents can lead to low productivity, reducing motivation to good agents in giving full commitment to their duties and possibly resulting in those agents leaving the takaful industry.

Followed by the behaviour of takaful agents that are unable to give a clear explanation, conflict of interest, and unprofessionalism shared the same frequency as much as three times the frequency. The behaviour of an agent who are unable to give a clear explanation is an agent that is lacking skill in communicating with the consumers. The lack of communication skills will cause the agent to have low confidence in providing information regarding takaful products and services to consumers. Therefore, the agents will fail to convince consumers about the quality of takaful products and services. Conflicts of interest between agents are also among the behaviour stated in previous studies. This conflict of interest exists when there is competition between the agents in a company. This may due to the agents competing to gain more consumers for themselves. 
INTERNATIONAL JOURNAL OF ACADEMIC RESEARCH IN BUSINESS AND SOCIAL SCIENCES

Vol. 8, No. 11, Nov, 2018, E-ISSN: 2222-6990 @ 2018 HRMARS

Subsequently, the number of frequencies that is shared twice is the behaviour of agents who do not understand the concept of takaful and the behaviour of hiding information about the takaful products and services. Chia Yi Cheng, Chia Hung hsieh and Yu Song Yang (2014) and Mei Fang Chen and Liang Hung Mau (2009) agree that one of the behaviour of takaful agents is the lack of understanding on the concept of takaful. Chia Yi Cheng, Chia Hung hsieh and Yu Song Yang (2014) also support the findings of Eastman, J.K., Eastman, K.L., and Drennan, R.B (1997) which states that agents have the behaviour to hide information regarding their products and services. Finally the number of frequencies only shown once is represented by agent behaviour that does know how the way of communication, behaviour of agent who persuades the consumer to choose a non-essential product, the behaviour of deliberately delaying the settlement claims, and the behaviour of failing to give a straight and honest answer to the consumers' request. Based on the analysis of previous studies, the researcher have summarized the behaviour of the agent in a table like in Table 2 below.

Table 2. Summary of the Behaviour of Agents

\begin{tabular}{|c|c|c|c|c|c|c|c|c|c|c|c|c|c|}
\hline \multirow[b]{2}{*}{ 을 } & \multirow[b]{2}{*}{ 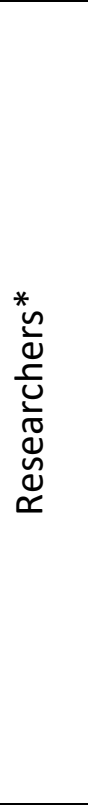 } & \multicolumn{12}{|c|}{ Agents'Behaviour } \\
\hline & & 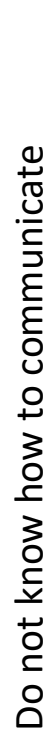 & 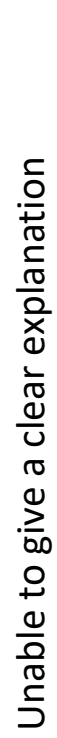 & 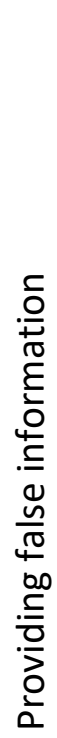 & 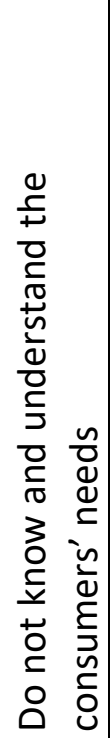 & 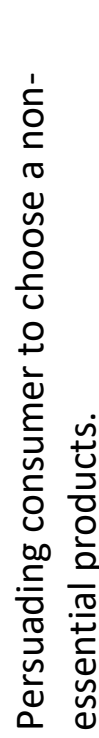 & 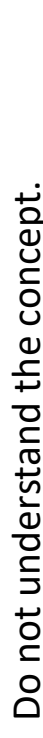 & 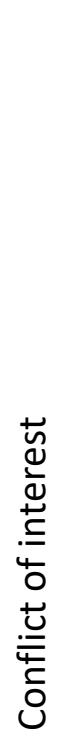 & 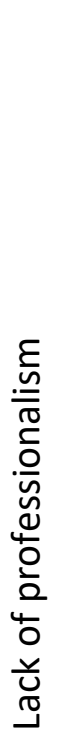 & 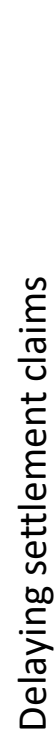 & 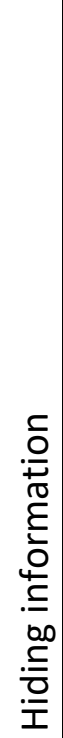 & 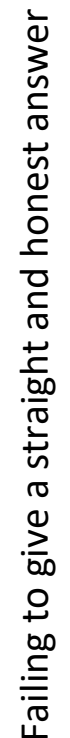 & 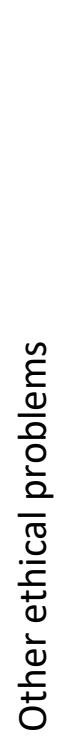 \\
\hline 1 & A & $v$ & $\sqrt{ }$ & & & & & & & & & & \\
\hline 2 & $B$ & & $\sqrt{ }$ & V & $\sqrt{ }$ & & 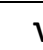 & $\mathrm{V}$ & & & $V$ & & V \\
\hline 3 & C & & $\sqrt{ }$ & $\mathrm{V}$ & $\sqrt{ }$ & & & & & & & & \\
\hline 4 & $\mathrm{D}$ & & & & $\sqrt{ }$ & & 1 & & & & & & \\
\hline 5 & $E$ & & & & & V & & & & & V & & \\
\hline 6 & $\mathrm{~F}$ & & & V & & & & & $\sqrt{ }$ & $\sqrt{ }$ & & & $\sqrt{ }$ \\
\hline 7 & G & & & & & & & & $\mathrm{V}$ & & & & \\
\hline 8 & $\mathrm{H}$ & & & & & & & $\mathrm{V}$ & & & & $\mathrm{V}$ & \\
\hline 9 & 1 & & & V & & & & & $\sqrt{ }$ & & & & $\checkmark$ \\
\hline 10 & $\mathrm{~J}$ & & & $\sqrt{ }$ & $\sqrt{ }$ & & & V & & & & & $\sqrt{ }$ \\
\hline \multicolumn{2}{|c|}{ Frequency } & 1 & 3 & 5 & 4 & 1 & 2 & 3 & 3 & 1 & 2 & 1 & 4 \\
\hline
\end{tabular}


INTERNATIONAL JOURNAL OF ACADEMIC RESEARCH IN BUSINESS AND SOCIAL SCIENCES Vol. 8, No. 11, Nov, 2018, E-ISSN: 2222-6990 @ 2018 HRMARS

*Researchers:
\begin{tabular}{|c|l|}
\hline A & Hamid, Ab Rahman, \& Nor (2012) \\
\hline B & Chia Yi Cheng, Chia Hung hsieh \& Yu Song Yang (2014) \\
\hline C & Aziz, Ghani, \& Shaari (2015) \\
\hline D & Mei Fang Chen \& Liang Hung Mau (2009) \\
\hline E & Eastman, J.K., Eastman, K.L., \& Drennan, R.B (1997) \\
\hline F & Ahmad \& Sungip (2008) \\
\hline G & Marcum and Robin (2003) \\
\hline H & Cooper \& Frank (2002) \\
\hline I & Howe, Hoffman \& Hardigree (1994) \\
\hline J & Cooper \& Frank (1991) \\
\hline
\end{tabular}

\section{Conclusion}

The behaviour of takaful agents that are identified in previous studies have shown that this is not a small problem as it can negatively affect the participation of takaful consumers. This is because the negative behaviour of takaful agents will affect some of the confidence and perceptions of consumers towards takaful. Agents play an important role as a liaison between consumers and the company. Therefore, it is very important for takaful agents to possess high credibility in order to establish good attitude and behaviour for the future of the takaful industry.

\section{Corresponding Author}

Nor Arini Binti Abdullah

Centre For Islamic Development Management Studies (ISDEV)

University of Science Malaysia, Penang

Email: arini_polaris@yahoo.com

\section{References}

Ghudah, A.B.A (2008) Nadwah A'a,iah Hawla al-Ta'min al Ta'wuni min Hilal Nizam Waqf:1-14

Ahmad, A., \& Sungip, Z. (2008). An assessment on service quality in Malaysia insurance industry. Communications of the IBIMA, 1, 13-26.

Aziz, N. A. A., Ghani, A. H. A., \& Shaari, H. (2016). Issues and problems in ethical practices amongst takaful agents. International Review of Management and Marketing, 6(4S), 21-26.

Billah, M. (2006). Takaful islamic insurance: An economic paradigm, 23(1), 76-86.

Borhan, J. T., \& Saari, C. Z. (2003). The principle of al-Takaful (collective responsibility) in Islam and its practice in the operations of Syarikat Takaful Malaysia Berhad. Jurnal Usuluddin, 17, 33-56.

Chen, M. F., \& Mau, L. H. (2009). The impacts of ethical sales behaviour on customer loyalty in the life insurance industry. The Service Industries Journal, 29(1), 59-74.

Cheng, C. Y., Hsieh, C. H., \& Yang, Y. S. (2014). Who would engage in unethical behavior? Should organizations bear the responsibility?. Quality \& Quantity, 48(4), 2341-2354.

Cooper, R. W., \& Frank, G. L. (1991). Ethics in the life insurance industry: The issues, helps, and hindrances. Journal of Financial Service Professionals, 45(5), 54. 
INTERNATIONAL JOURNAL OF ACADEMIC RESEARCH IN BUSINESS AND SOCIAL SCIENCES

Vol. 8, No. 11, Nov, 2018, E-ISSN: 2222-6990 C 2018 HRMARS

Cooper, R. W., \& Frank, G. L. (2002). Ethical challenges in the two main segments of the insurance industry: Key considerations in the evolving financial services marketplace. Journal of Business Ethics, 36(1-2), 5-20

Eastman, J. K., Eastman, K. L., \& Drennan, R. B. (1997). The ehics of insurance agents vs. insurance students: The educational implications. CPCU JOURNAL, 50, 104-120..

Hamid, M. A., Ab Rahman, N. M. N., \& Nor, N. M. (2012). Leadership behavior and performance: A case study of takaful representatives in Malaysia. African Journal of Business Management, 6(6), 2291-2298.

Howe, V., Hoffman, K. D., \& Hardigree, D. W. (1994). The relationship between ethical and customeroriented service provider behaviors. Journal of Business Ethics, 13(7), 497-506.

Isa, M., \& Deni, M. (2009). Perkembangan sistem takaful di Malaysia: keprihatinan di kalangan siswazah (Doctoral dissertation, Universiti Utara Malaysia).

Mahmud, M. S., \& Kader, R. A. (2012). Perkembangan takaful di Malaysia: satu kajian undang-undang kewangan Islam. Kanun Jurnal Undang-Undang Malaysia 24 no, 2, 252-259.

Marcum, W. M., \& Robin, D. P. (2003). Accessing and understanding the ethical attitudes of insurance practitioners. CPCU eJournal, 58(5), 1-14.

Mohd Noor, A., \& Zakaria, M. S. (2010). Takaful: analisis terhadap konsep dan akad. Jurnal Muamalat, 1(3), 1-28. 